This document is confidential and is proprietary to the American Chemical Society and its authors. Do not copy or disclose without written permission. If you have received this item in error, notify the sender and delete all copies.

\title{
A Pentaplex PCR as screening assay for jellyfish species identification in food products.
}

\begin{tabular}{|r|l|}
\hline Journal: & Journal of Agricultural and Food Chemistry \\
\hline Manuscript ID: & jf-2014-04654b.R1 \\
\hline Manuscript Type: & Article \\
\hline Date Submitted by the Author: & $\mathrm{n} / \mathrm{a}$ \\
\hline Complete List of Authors: & $\begin{array}{l}\text { Armani, Andrea; University of Pisa, Department of Veterinary Sceinces } \\
\text { Giusti, Alice; University of Pisa, Department of Veterinary Sciences } \\
\text { Castigliego, Lorenzo; University of Pisa, Department of Veterinary Sciences } \\
\text { Rossi, Aurelio; University of Pisa, Department of Veterinary Sciences } \\
\text { Tinacci, Lara; University of Pisa, Department of Veterinary Sciences } \\
\text { Gianfalodni, Daniela; University of Pisa, Department of Veterinary Sciences } \\
\text { Guidi, Alessandra; University of Pisa, Department of Veterinary Sciences }\end{array}$ \\
\hline
\end{tabular}

\section{SCHOLARONE ${ }^{\text {Th }}$}

Manuscripts 
A Pentaplex PCR as screening assay for jellyfish species identification in food products.

2

3 Andrea Armani*, Alice Giusti, Lorenzo Castigliego, Aurelio Rossi, Lara Tinacci, Daniela 4 Gianfaldoni, Alessandra Guidi.

5

6 FishLab, Department of Veterinary Sciences, University of Pisa, Via delle Piagge 2, 56124, Pisa 7 (Italy).

8

9

10

11

12

13

14

15

16

17

18

19

20

$21 *$ corresponding author:

22 Postal address: FishLab (http://fishlab.vet.unipi.it), Department of Veterinary Sciences,

23 University of Pisa, Via delle Piagge 2, 56124, Pisa (Italy)

24 Tel: +390502210207

25 Fax: +390502210213

26 Email: andrea.armani@unipi.it; 


\section{Abstract}

Salted Jellyfish, a traditional food in Asian Countries, is nowadays spreading on the Western markets. In this work, we developed a Pentaplex PCR for the identification of 5 edible species (Nemopilema nomurai, Rhopilema esculentum, Rhizostoma pulmo, Pelagia noctiluca, and Cotylorhiza tuberculata), which cannot be identified by a mere visual inspection in jellyfish products sold as food. A common degenerated forward primer and 5 specie-specific reverse primers were designed to amplify $C O I$ gene regions of different lengths. Another primer pair was targeted to the $28 \operatorname{Sr} R N A$ gene and intended as common positive reaction control. Considering the high level of degradation in the DNA extracted from acidified and salted products, the maximum length of the amplicons was set at 200bp. The PCR was developed using 66 reference DNA samples. It gave successful amplifications in $85.4 \%$ of 48 Ready to Eat products (RE) and in $60 \%$ of 30 Classical salted Products (CP) collected on the market.

Keywords: Multiplex PCR; Jellyfish; Species identification; COI gene; seafood mislabeling

(1)

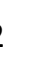

(1)

4
(1)

(1)

\section{8} 4 so 31 


\section{Introduction}

In the last decades, Jellyfish proliferation in coastal areas, often referred to as "blooming", has become a reason of concern due to damages to aquaculture, clogging of the cooling systems of coastal power plants, and stings of bathers ${ }^{1}$. Moreover, the fact that jellyfish may feed on fish larvae, further decreasing the resilience of fish populations already weakened by over-fishing, is an emerging ecological and economical issue ${ }^{2}$.

The Food and Agriculture Organization of the United Nations (FAO) has recently proposed to reduce jellyfish populations by increasing their utilization as medicine or food $^{3}$, considering that their biomass could be a valuable source of bioactive compounds and nutrients.

Both Asian and Mediterranean jellyfish are characterized by a number of metabolites with a healthy potential: extracts from Nemopilema nomurai, Rhopilema esculentum, Pelagia noctiluca, and Cotylorhiza tuberculata were reported to have hemolytic, anti-tumoral, antioxidant, antimicrobial, and insecticidal activity ${ }^{4-7}$. The collagen of some species has been demonstrated to possess the same characteristics of that of human origin ${ }^{8}$ and the collagen of Rhizostoma pulmo is considered as a good candidate for replacing the bovine collagen in biomedical applications ${ }^{9}$.

Regarding the utilization as food, while in the past the jellyfish was exclusively exploited in the Eastern Asia ${ }^{10}$, nowadays, due to the worldwide migration flows from China, the jellyfish based products are increasingly spreading even in the Western Countries ${ }^{11,12}$. Two different kinds of products are available on the market: the Classical Salted Products (CP), which needs a long washing before consumption, due to the high salt concentration, and the new "ready to eat" products (RE), already desalted ${ }^{10}$.

Even though more than 15 edible species belonging to the Rhizostomeae order could be used as food, a recent molecular survey performed on the European market ${ }^{12}$ has highlighted that the jellyfish based products were essentially prepared using two big Asian species of the Rhizostomatidae family: N. nomurai and R. esculentum. However, a small percentage of the analyzed products were $P$. noctiluca and $R$. pulmo. 
In the European Union, the Regulation (EC) n. $2065 / 2001^{13}$ lists the information to be provided for labeling of fishery products. These are the commercial and scientific designation of the species, the production method, and the catch area. Furthermore, the recent Regulation (EU) n. 1379/2013 ${ }^{14}$, which will be applied from the 13th December 2014, established that the category of fishing gear used for the capture must also be reported.

Unfortunately, labelling of the ethnic products often presents incongruences and deficits with respect to the mandatory information requested. D'Amico et al. ${ }^{15}$ found that a very high percentage of Chinese seafood products imported in Italy do not meet EU requirements on traceability. In a previous survey, it has been found that labels of jellyfish products not only missed an unequivocal specification of ingredients, but were also labelled with a trade name referring to vegetables ${ }^{11}$.

One of the main problems associated with the inspection of jellyfish products, related to the loss of their morphological characteristics during processing, is the impossibility to unambiguously identify the species used ${ }^{12}$. For this reason, it is necessary to rely on laboratory methods. Among these, those based on the analysis of nucleic acids are the most used in case of fish and seafood $\operatorname{products}^{16,17}$.

Polymerase chain reaction (PCR), the technique of choice for species identification, is often coupled with sequencing, which is used to determine the precise order of nucleotides in a DNA molecule ${ }^{16,18}$. FINS (Forensically Informative Nucleotide Sequencing) combines DNA sequencing with a phylogenetic analysis ${ }^{19}$. The development of the DNA Barcoding, an evolution of the FINS method, has determined the increase of use of the cytochrome c oxidase I gene $(C O I)$ as a genetic marker for species identification ${ }^{20,21}$. In a previous work $^{12}$ we showed that a specific pre-DNA extraction treatment, coupled with FINS of a 142bp COI gene fragment, allowed the molecular identification of jellyfish species, also in case of salted products, in which the DNA is heavily degraded.

Considering that FINS is often limited by high costs and long-time of execution, in this work an alternative method to be used with screening purposes was developed to minimize expenses and 
104

105

106

107

108

109

110

111

112

113

114

115

116

117

118

119

120

121

122

123

124

125

126

127

128

129

save time. This new method, a Pentaplex PCR assay, is capable to identify two Asian jellyfish commonly used as food, such as $N$. nomurai and $R$. esculentum, and another 3 species distributed in the Mediterranean Sea, such as R. pulmo, P. noctiluca, and C. tuberculata, which could represent a novel business for the industry. This is possible by using a common forward primer together with 5 specific reverse primers, capable to amplify 5 regions with different size of the COI gene. This method can be used as rapid test for checking commercial samples, in which the diagnostic morphological characteristics have been lost.

\section{Materials and methods}

\subsection{Jellyfish reference (RS) and market samples (MS) collection}

Nine samples belonging to the species Aurelia sp., C. tuberculata, and P. noctiluca were kindly provided by the Institute of Sciences of Food Production of the National Research Council of Lecce (Table 1SI).

\subsection{DNA extraction}

All the jellyfish RS were extracted according to the protocol proposed by Armani et al. ${ }^{22}$ The amount of DNA was determined with a NanoDrop ND-1000 spectrophotometer (NanoDrop Technologies, Wilmington, DE, USA) by measuring the absorbance at $260 \mathrm{~nm}$. DNA samples obtained from 57 jellyfish RS (Table 1SI) and 78 MS (Table 1), all of them molecularly identified in a previous work ${ }^{22}$, were also used to develop and validate the Pentaplex PCR. Finally, 3 DNA samples of $R$. luteum from the study of Prieto et al. ${ }^{23}$ and 6 DNA samples of $P$. benovici from the study of Piraino et al. ${ }^{24}$ were used.

\subsection{Amplification of COI and 28SrRNA genes}

2.3.1. COI. All the DNA reference samples extracted in this study from jellyfish were initially amplified using the primers FFDL and FRDL2 ${ }^{12}$ to obtain the first $655 \mathrm{bp}$ of the $m t C O I$ gene. The samples that failed the amplification were subsequently amplified using internal reverse primers ${ }^{12}$ in combination with the same forward primer. The DNA was amplified according to the following PCR protocol: $20 \mu \mathrm{L}$ of reaction volume containing $2 \mu \mathrm{L}$ of $10 \times$ buffer (5Prime, Gaithersburg, 
USA), $200 \mu \mathrm{M}$ of each dNTP (dNTPmix, Euroclone S.p.A-Life Sciences Division, Pavia, Italy), $300 \mathrm{nM}$ of primers, $25 \mathrm{ng} / \mu \mathrm{L}$ of BSA (Purified BSA 100×, New England BIOLABS ${ }^{\circledR}$ Inc. Ipswich, MA, USA), 1.25 U of PerfectTaq DNA Polymerase (5Prime, Gaithersburg, USA), 100 ng of DNA and DNase free water (Water Mol. Bio. Grade, DNase-RNase and Protease free, 5Prime GmbH, Hamburg, Germany), with the following cycling program: denaturation at $94{ }^{\circ} \mathrm{C}$ for $3 \mathrm{~min} ; 40$ cycles at $94{ }^{\circ} \mathrm{C}$ for $30 \mathrm{~s}, 51{ }^{\circ} \mathrm{C}$ for $30 \mathrm{~s}$, and $72{ }^{\circ} \mathrm{C}$ for $35 \mathrm{~s}$; final extension at $72{ }^{\circ} \mathrm{C}$ for $5 \mathrm{~min}$. Five $\mu \mathrm{L}$ of PCR products were checked by gel electrophoresis on a $2 \%$ agarose gel and the presence of fragments of the expected length was assessed by a comparison with the standard marker SharpMass ${ }^{\mathrm{TM}} 50-\mathrm{DNA}$ ladder (Euroclone, Wetherby, UK). Double-stranded PCR products were purified with the Illustra ExoProStar 1-Step Enzimatic PCR and Sequencing Clean-Up (GE Healthcare UK Limited, Amersham Place Little Chalfont Buckinghamshire, UK) following the manufacturer's instruction and then sequenced by GATC Biotech (Germany). The obtained sequences were analyzed using ClustalW in MEGA $5.0^{25}$. Fine adjustments were manually made after visual inspection. All the sequences were used to run a BLAST analysis on GenBank (http://blast.ncbi.nlm.nih.gov/Blast.cgi) and analyzed using the Identification System (IDS) on BOLD (Species Level Barcode Records) (http://www.boldsystems.org/index.php/IDS_OpenIdEngine). Finally, the sequences were deposited on GenBank via EBI (Table 1SI).

2.3.2. $28 S$ rDNA. The $28 S r R N A$ gene sequences belonging to the Order Rhizostomeae and Semaestomeae produced in the work of Bayha et al. ${ }^{26}$ were downloaded from GenBank and aligned using Clustal $\mathrm{W}$ in MEGA 5.0. The overall mean distance was calculated using the Kimura 2parameter model ${ }^{27}$ on a fragment of $1480 \mathrm{bp}$. Then, a new couple of primers (F28S and R28S) (Table 2) were designed for the amplification of a fragment of $\sim 1600 \mathrm{bp}$ from the DNA of $N$. nomurai using the same PCR mix described for the COI gene, with the following cycling program: denaturation at $94{ }^{\circ} \mathrm{C}$ for $3 \mathrm{~min} ; 40$ cycles at $94{ }^{\circ} \mathrm{C}$ for $30 \mathrm{~s}, 51^{\circ} \mathrm{C}$ for $30 \mathrm{~s}$, and $72{ }^{\circ} \mathrm{C}$ for $35 \mathrm{~s}$; final 
155

156

157

158

159

160

161

162

163

164

165

166

167

168

169

170

171

172

173

174

175

176

177

178

179

180

extension at $72{ }^{\circ} \mathrm{C}$ for $10 \mathrm{~min}$. The sequences were analyzed as reported in section 2.3.1. and were deposited on GenBank via EBI (Table 1SI).

\subsection{Primer Design for the Pentaplex PCR Assay.}

2.4.1. Specie-specific primers targeting the COI gene. Six hundred sixty six mtCOI sequences belonging to 24 species (Table 3) were aligned with Clustal W in MEGA 5.0. Then, two hypothetical common forward primers were designed (FJ1 and FJ2, Table 2) by modifying the primer FFDL designed in a previous work ${ }^{12}$. The reverse primers were designed on highly polymorphic regions for the amplification of fragments of different length in the range of 50-200bp. Primers score were calculated with the software Beacon designer 7.0 (Premier Biosoft International, Palo Alto, CA) and with the software available on the Eurofins MWG Operon (Ebersberg, Germany) page (http://www.eurofinsgenomics.eu/). The number of mismatches between the reverse primers and the annealing region of the no-target species (Table 2SI) was also taken into consideration as criterion to select specie-specific primers. Totally 11 primers, 2 forward and 9 reverse, were synthetized by the Eurofins MWG Operon.

\subsubsection{Control PCR primers targeting the 28SrRNA gene}

With the aim of amplifying in all the species, a control fragment of 55bp together with the species-specific fragment, two primers (28sfor55 and 28srev55) (Table 2) were designed on highly conserved regions using the software Beacon designer 7.0 after aligning the $28 S R R A$ gene sequences (Order Rhizostomeae and Semaestomeae) produced in the work of Bayha et al. ${ }^{26}$ with the sequences of $N$. nomurai produced in this study.

\subsection{PCR reaction optimization}

The two forward primers were tested on the DNA of all the reference species in single reaction with each of the reverse primers designed (Table 1SI). The primers capable to amplify the target sequence without producing unspecific bands were selected (Table 2).

All the primers were tested in combination in the same PCR reaction mix using different concentrations (from 100 to $400 \mathrm{nM}$ ), in presence of increasing concentration of $\mathrm{MgCl}_{2}(1 ; 2$; and 5 
$\mathrm{mM}$ ) and nucleotides (from 200 to $600 \mu \mathrm{M}$ ). We also tested different amount of total DNA (from 1 to $200 \mathrm{ng}$ ) and of Taq polymerase (1X and $2 \mathrm{X})$. The optimal annealing temperature was selected after trials in the range of $47^{\circ} \mathrm{C}$ to $51^{\circ} \mathrm{C}$, on a PeqStar 96 Universal Gradient, PEQLAB BiotechnologieGmgH (Euroclone, Wetherby, UK). The control PCR primers were initially tested on all the reference DNA samples and then included in the multiplex reaction. The reaction protocol that showed the best amplification performances was tested on 10 samples of not degraded DNA extracted from 5CP and 5RE to verify the output of the Pentaplex method in case of degraded and low quality DNA.

\subsection{Final Pentaplex PCR protocol and analysis of commercial samples}

The following final protocol: $10 \mu \mathrm{L}$ of reaction volume containing $1 \mu \mathrm{L}$ of $10 \times$ buffer (Fisher Molecular Biology, Trevose PA, USA), $400 \mu \mathrm{M}$ of each dNTP (dNTPmix, Euroclone S.p.A-Life Sciences Division, Pavia, Italy), 300 nM of FJ2, 200 nM COT2, 200 nM RHOP1-1, 225 nM NEMO1, $200 \mathrm{nM}$ PEL1 and $100 \mathrm{nM}$ RHIZ1-1reverse primers, $100 \mathrm{nM}$ of 28sfor55 and 28srev55 control primers, $25 \mathrm{ng} / \mu \mathrm{L}$ of BSA (Purified BSA 100×, New England BIOLABS ${ }^{\circ}$ Inc. Ipswich, MA, USA), 1 U of SubTherm TAQ Polymerase (Fisher Molecular Biology, Trevose PA, USA), 3 $\mathrm{mM}$ of $\mathrm{MgCl}_{2}, 50 \mathrm{ng}$ of DNA and DNase free water with the following cycling conditions: denaturation at $95{ }^{\circ} \mathrm{C}$ for $3 \mathrm{~min} ; 40$ cycles at $95{ }^{\circ} \mathrm{C}$ for $25 \mathrm{~s}, 49^{\circ} \mathrm{C}$ for $5 \mathrm{~s}$, and $72{ }^{\circ} \mathrm{C}$ for $5 \mathrm{~s}$; final extension at $72{ }^{\circ} \mathrm{C}$ for $5 \mathrm{~min}$. The electrophoresis was performed using a $4 \%$ agarose gel. In case of MS DNA, the length of the specific bands obtained with the multiplex PCR was compared to the results of the BLAST analysis performed on the same samples in a previous article ${ }^{12}$ (Table 1), with the aim to assess the efficiency and specificity of the assay in case of low quality DNA.

\section{Results and Discussion}

Seafood species identification has gained increasing importance in the current global market context. In fact, many studies, carried out in different geographical areas, have highlighted that almost one third of the commercialized seafood is made of a different species with respect to what 
206 declared on the label ${ }^{20,21}$. In some cases, the substitution rate can reach alarming levels, as in the 207 case of jellyfish products ${ }^{12}$.

208 In this light, the diagnostic techniques, particularly those based on DNA analysis, may assist 209 both private companies and official agencies in ensuring a fair commerce in the light of the traceability regulations. Among the available methods, the multiplex PCR has the advantage to allow considerable saving of time and labor. This methods have been successfully used for several different purposes of identification, fish species included ${ }^{28,29}$. human consumption ${ }^{10,12}$.

As for the other species selected as target for the Pentaplex PCR, the R. pulmo was chosen due to the fact that it is one of the largest and most abundant jellyfish exclusively distributed in the

\subsection{Selection of the species and of the DNA target}

3.1.1 Species selection. R. esculentum and N. nomurai are the Asian species most exploited for Mediterranean Sea and adjacent $\operatorname{areas}^{30}$. The utilization of this Mediterranean jellyfish for food preparation was suggested in the work of Muhammed and Sultana ${ }^{31}$ and by the fact that an Italian company has recently started to process $R$. pulmo for exportation to the Japanese market (author's note). Finally, Chinese people use to collect jellyfish aground on beaches and to buy jellyfish from fishermen along the Tyrrhenian coast of Italy $^{12}$. C. tuberculata and P. noctiluca are also widely distributed in the Mediterranean Sea ${ }^{32,33}$. They may likely be used as food products owing to their anatomical features and wide distribution (http://www.lagazzettadelmezzogiorno.it/notizienascoste/meduse-buone-anche-in-cucina-e-contro-1-ipertensione-no619007/). As support of this, the molecular analyzes carried out in a previous work ${ }^{12}$ have identified the presence of the species $P$. noctiluca in some commercial products.

3.1.2 DNA target selection. The selection of a mitochondrial molecular marker is based on its several advantages with respect to the nuclear markers, such as the higher number of copies and the greater resistance to degradation induced by chemical-physical treatments. Moreover, the higher degree of interspecific variability is particularly useful for discrimination of species very close from 
232 a phylogenetic point of view ${ }^{16,18}$. Among the mitochondrial markers most used for seafood 233 authentication (COI, $16 \operatorname{srDNA}$, and $c y t b)$, in this study, the COI gene was chosen due the 234 availability of a higher number of reference sequences (Table 3). In fact, the creation of the Barcode 235 of Life Data Systems database (BOLD) (http://www.boldsystems.org/) has gained the attention of 236 many researchers worldwide making the first $650 \mathrm{bp}$ of the COI region one the most targeted 237 mtDNA region for species identification ${ }^{20,21,34}$. Furthermore, the $C O I$ gene was found to be enough 238 informative to allow the identification of edible jellyfish species ${ }^{12}$.

\subsection{Primer design}

3.2.1. Specie-specific primers targeting the COI gene. One of the main points to take into consideration during primers designing is the nature of the sample to be analyzed. In fact, a net difference exists between fresh and processed products: technological treatments, such as heating, acidification pressurization or their combination may negatively influence the integrity of DNA and hence the PCR outputs ${ }^{18}$. In particular, heat treatment and sharp shifts of $\mathrm{pH}$ were identified as the main DNA degrading factors in food ${ }^{35}$.

In a previous work ${ }^{12}$, we found that jellyfish products were characterized by very low $\mathrm{pH}$ values: $\sim 4$ and $\sim 6$ in CP and RE, respectively. Despite a certain level of DNA degradation, we were able to amplify bands of about $700 \mathrm{bp}$ in the $75 \%$ of the DNA extracted from RE samples and in the $44 \%$ of the DNA extracted from CP samples. However, in 100\% of the DNA extracted from both kind of products, it was possible to obtain amplicons of $\sim 200 \mathrm{bp}$. For this reason, in this work the primers were designed in such a way as to produce amplicons with a maximum length of 200bp (Table 2).

With the aim to decrease the probability of template-independent primer interactions during amplification, which is greater in a multiplex PCR than in a uniplex, we decided to design a common forward primer (FJ2). This approach was successfully used to develop other methods based on multiplex $\mathrm{PCR}^{28,29}$. Considering the high variability of the $C O I$ gene, which makes difficult to find a common conserved region among 5 different species, we decided to design a degenerated primer. This was designed by modifying the forward primers proposed in a previous 
258 work $^{12}$, while the reverse primers were designed on a polymorphic region of the COI gene. Once 259 tested in single and multiplex reactions, the reverse primers PEL1, NEMO1 showed a high specificity for their target species ( $P$. noctiluca and $N$. nomurai), producing the expected amplicon of 165 and $143 \mathrm{bp}$, respectively. No bands were obtained in case of DNA samples belonging to other jellyfish species of the Rhizostomeae and Semaestomeae order (Table 1SI). Interestingly, the primer PEL1 was able to amplify the DNA of P. noctiluca but not the DNA of P. benovici, a new Pelagia species recently described by Piraino et al. ${ }^{24}$ For these reasons the reverse PEL1, NEMO1 were selected without modifications, which, on the contrary, were necessary for RHIZ1, RHOP1, and COT1.

The original RHIZ1 reverse primer gave the expected amplicon of $203 \mathrm{bp}$ on all the species belonging to the genus Rhizostoma, which, according to Russell ${ }^{30}$ is composed of $R$. pulmo, $R$. octopus and R. luteum. While a recent study of Prieto et al. ${ }^{23}$, on the basis of morphological and molecular results, confirmed that $R$. luteum is a distinct species with respect to the other two, the status of $R$. octopus is still controversial. In fact, $\mathrm{Kramp}^{36}$ considered $R$. luteum as a variant of $R$. pulmo and Holst et al. ${ }^{37}$ advocated that detailed morphological studies and molecular analyses are needed to better define the relationships among Rhizostoma species. For these reason, the pairwise Kimura 2-parameter molecular divergence between $R$. pulmo and $R$. octopus COI sequences (Table 3) was calculated. The low values found (6\%) suggest that $R$. pulmo and R. octopus cannot be unquestionably considered as distinct species by a molecular point of view, supporting the theory of $\mathrm{Kramp}^{36}$. In fact, the literature suggests that $10-20 \%$ COI sequence divergence may be a suitable benchmark value to define species ${ }^{38}$.

In the light of this considerations, the reverse primer RHIZ1 was improved: two new primers were produced (Table 2) by introducing single (RHIZ1-1) and multiple (RHIZ1-2) base modification at different positions, with the aim to create additional mismatches on the annealing region of $R$. luteum COI sequence. RHIZ1-2 was discarded due to its inability to amplify the DNA 
283 of both Rhizostoma species, while the reverse RHIZ1-1 was selected for its specificity in uniquely 284 amplifying the DNA of R. pulmo.

285 The primer RHOP1 produced the $101 \mathrm{bp}$ amplicon from the DNA of $P$. benovici, other than of $R$. esculentum, due to the presence of only one difference on the annealing sequence of the two species. For these reason, the primer RHOP1 was modified (RHOP1-1) near to the 3'-end. In fact, mismatch at or near the terminal $3^{\prime}$ base of a primer affects PCR more dramatically than those single mismatches located internally or at $5^{\prime}$ end ${ }^{39}$. The new primer RHOP1-1 gave the expected amplicon only in presence of DNA of $R$. esculentum. Likely, selectivity of amplification using these primers has been increased by the stringent conditions adopted for the amplification protocol (see section 2.6). In fact, to avoid unspecific amplification we used an annealing time of only $5 \mathrm{sec}$.

Finally, even though specific, the reverse primers COT1 was re-designed (COT2) due to its low amplification performance.

\subsubsection{Control PCR primers targeting 28SrRNA gene}

The extraction of DNA contaminated by inhibitors is one of the main obstacles associated with PCR application in complex matrices, such as food. In fact, the inhibitors can interfere with the reaction, even leading to a complete amplification inhibition ${ }^{18}$. In our previous study ${ }^{12}$, we found that $\mathrm{Al}^{3+}$ ions may contribute to the overall DNA amplification failure. In fact, the initial concentration of the aluminum in jellyfish food products is extremely different ${ }^{12,40}$ and, even though the pre-extraction procedure can reduce its concentration, it is impossible to predict the residual amount in different DNA samples. Therefore, considering that inhibition may be the cause of falsenegative reactions, we decided to introduce a reaction control. This consideration, together with the high degradation level of the DNA extracted from MS, led us to design control primers for the amplification of a short DNA fragment of 55bp.

Ribosomal genes, such as the $16 s R N A$ gene, are characterized by a low mutation rate ${ }^{41}$. In this study, the overall mean distance calculated on a fragment of $1480 \mathrm{bp}$ belonging to the $28 \mathrm{r}$ rNA gene sequences (those produced by Bayha et al. ${ }^{26}$ together with the sequence of $N$. nomurai 
309

310

311

312

313

314

315

produced in this study) was $2 \%$. In the light of these results and taking into consideration that in a previous study ${ }^{28}$ the high degree of conservation has played a decisive role for designing primers to be used for the amplification of many species at once, the $28 S r R N A$ gene was selected as target for designing the control primers.

\subsection{Pentaplex PCR assay: development and final protocol}

The optimization of a multiplex PCR can imply several difficulties. In fact, the presence of more than one primer pair in the reaction increases the chance of obtaining spurious amplification products and may increase the possibility to obtain the formation of primer dimers. Increasing the concentration of PCR reagents during the optimization step can increase the likelihood of mispriming, with subsequent production of nonspecific amplification ${ }^{42}$. However, optimization of these components is usually beneficial. For the aforesaid reasons the final reaction protocol was selected through a process in which different concentration of primers, $\mathrm{MgCl}_{2}$, nucelotides, and Taq polymerase were tested. In the meanwhile, the best cycling conditions were selected by testing different temperatures and times.

3.3.1. Primers and DNA template amount. The primers were used at the same concentration during the first trials $(100 \mathrm{nM})$. Subsequently, the concentrations were modified with the aim to obtain bands of similar intensity. In general, due to the good efficiency of the reverse primers, the concentration was maintained in the range of 100-200 nM. Only the degenerated forward primer was used at a higher concentration $(300 \mathrm{nM})$. Overall, primers' concentrations were lower than those at which it was observed the formation of considerable amount of primer-dimer $(\sim 500 \mathrm{nM})^{42}$. We found that the introduction of the control primers (28sfor55; 28srev55) reduced the amplification efficiency of some specific primers (PEL1 and NEMO1), even when used at low concentration $(50,100 \mathrm{nM})$. For this reason, both nucleotides and Taq polymerase concentration were increased (see section 3.3.3).

Another fundamental step for the obtaining of a specific amplification, strictly connected with primers concentration, is the selection of an adequate DNA template concentration. In fact, if the 
335 primer-to-template ratio is too low, specific products will not accumulate exponentially while 336 primer dimers may be amplified more efficiently than the desired target ${ }^{42,43}$. In this study, the 337 utilization of total DNA quantities between 50 and $200 \mathrm{ng}$ per reaction did not bring any significant 338 difference regarding bands intensity. On the contrary, DNA quantities over 100 ng negatively 339 affected the background of the gel after electrophoresis, especially in case of DNA extracted from 340 market samples. In fact, when degradation of DNA occurs, small DNA fragments may 341 unspecifically be involved in the reaction, producing spurious amplification products. For this 342 reason $50 \mathrm{ng}$ were used as working concentration.

3.3.2. $\mathrm{MgCl}_{2}$, nucelotides and Taq polymerase. To test the influence of $\mathrm{MgCl}_{2}$ different trials were performed keeping constant the dNTP concentration and gradually increasing magnesium chloride from 1 to $5 \mathrm{mM}$. Using the standard concentration of dNTP $(200 \mu \mathrm{M})$, the amplification became more specific and the products acquired comparable intensities at $3 \mathrm{mM}$ : further increase showed a detrimental effect. Then, considering that in a multiplex PCR more amplicons are simultaneously amplified and the pool of enzymes and nucleotides becomes a limiting factor ${ }^{44}$, and in the light of the results obtained after the addition to the reaction mixture of the control primers, we decided to test doubled concentration of these reagents $(400 \mu \mathrm{M}$ of dNTP and $1 \mathrm{U}$ of TAQ Polymerase). The reaction efficiency was sensibly improved and, even though dNTPs directly chelate a proportional number of $\mathrm{Mg}^{2+}$ ions, we did not find any advantage using higher concentration of $\mathrm{MgCl}_{2}$.

3.3.3 Cycling condition. All the primer pairs used in a multiplex PCR should enable similar amplification efficiencies for their respective targets. This may be achieved through the utilization 356 of primers with very similar optimum annealing temperatures. In this work, the average melting temperature of the species-specific reverse primers was $50.5^{\circ} \mathrm{C}$, while the degenerated reverse has a melting temperature of $53.7^{\circ} \mathrm{C}$. Even though our primers produced the expected amplicon in the range of $47-51^{\circ} \mathrm{C}$, an annealing temperature of $49^{\circ} \mathrm{C}$ was selected. This temperature facilitate the annealing of the degenerated FJ2 primer and increased the specificity of the reverse primers. This 
361 probably has enhanced the specificity of our Pentaplex method allowing to avoid unspecific 362 amplification even in case of close species.

\subsection{Validation of the Pentaplex PCR assay using market samples DNA}

Once optimized on DNA extracted from RS and part of the MS (Figure 1), the final Pentaplex PCR protocol was applied to all the DNA samples extracted from MS identified by FINS in a previous work $^{12}$. In particular, $48 \mathrm{RE}$ and $30 \mathrm{CP}$ DNA samples were tested. The results of the amplification are reported in Table 1, while the percentages of successful amplification are summarized in Table 4. Overall, in the case of RE, the Pentaplex PCR was capable to specifically amplify $85.4 \%$ of DNA. The higher percentage of amplification (95\%) was obtained using those DNA samples from which a sequence of 658bp (amplicon including primers of 709bp) was previously amplified, while lower percentages were obtained in case of more degraded DNA samples (Table 4). In case of DNA extracted from CP, the Pentaplex PCR was less effective. Overall, it was able to correctly amplify $\sim 60 \%$ of tested samples. Moreover, the absence of specific amplicons in $3 \mathrm{CP}$ sample that have not been identified at the species level by the phylogenetical analysis (identity value of $86 \%$ with $N$. nomadica and $85 \%$ with $C$. stuhlmanni) can be considered as a further demonstration of the specificity of the proposed method.

The lower rate of success in case of $\mathrm{CP}$ with respect to $\mathrm{RE}$ could be attributed to the presence of strongly degraded DNA extracted from products characterized by lower $\mathrm{pH}$ values (see section 3.2.1), or other than to the action of inhibitors, such as aluminum. In fact, in all the DNA from which the specie-specific band was not obtained, the 55bp control amplicon was always visible (Figure 1). Furthermore, in a previous study ${ }^{12}$ we found that the inhibitory effects affected more the longest than the shortest ones.

This results might seem to be in contrast with those obtained in our previous study ${ }^{12}$, in which an amplicon of $145 \mathrm{bp}$ was amplified even from the most degraded DNA from market samples. One possible explanation could be related to the more stringent cycling conditions adopted to increase specificity. In PCR protocols using degenerated primers, the difference between the melting (MT) 
387 and the annealing temperature (AT) should be in between 10 and $20^{\circ} \mathrm{C}^{45}$. In the previous work, in 388 which only degenerated primers were used, AT was $9^{\circ} \mathrm{C}$ lower than the mean MT of the primers. In 389 this Pentaplex PCR, the low difference $\left(4.7^{\circ} \mathrm{C}\right)$ between MT and AT of primers could have led to a 390 more difficult annealing. Finally, multiplex PCRs are proven to be less sensitive than single PCR 391 reactions ${ }^{46}$.

\subsection{Jellyfish labeling: issues and outlooks}

All the jellyfish recorded in FAO statistics belong to the order Rhizostomeae and in particular to the genus Rhopilema ${ }^{47}$. These statistics are quite questionable considering that at least 11 species in 5 families are known to be exploited worldwide.

Most of the Asian jellyfish are exported to Japan and the remainder are sold to South Korea,

397 Taiwan, Singapore, Hong Kong, USA ${ }^{10,48}$, and Europe ${ }^{11,12}$. While in the Eastern Asian Countries 398 the jellyfish food products are usually categorized in 8 types based on the color, form, texture, and 399 size of the semi-dried products ${ }^{48}$, the Western Countries have tried to regulate the 400 commercialization of these products by establishing a specific labeling.

401 In USA, the acceptable market name of jellyfish has been associated to all the species belonging 402 to the genus Rhopilema 403 (http://www.accessdata.fda.gov/scripts/fdcc/?set=seafoodlist\&id=\%3Ci\%3ERhopilema\%3C/i\%3E $404 \% 20$ spp.\&sort=SLSN\&order=ASC\&startrow=1\&type=basic\&search=jellyfish)..$\quad$ In $\quad$ Italy, the 405 Ministry of Agriculture Food and Forestry Policies (MIPAFF) has adopted the provisional 406 commercial denomination of "Asian jellyfish" for the species $R$. esculentum. At present, to the best 407 of our knowledge, no other EU member Countries has defined a commercial denomination for 408 jellyfish species.

409 We think that, due to the impossibility to identify the species in the commodity by a visual 410 inspection, some traceability information, as for example the commercial and scientific 411 denomination, have been deduced at official level from the importation documents. In fact, animal 412 products from Third Countries outside the EU must be imported via a port or an airport with a 
413 Border Inspection Post (BIP), the official office authorized by the Ministry of Health in performing 414 the control according to the European legislation. In fact, the official controls shall include at least a 415 systematic documentary check, a random identity check and, where appropriate, a physical check. 416 However, physical check, which could include checks on the means of transport, on the packaging, 417 labelling and temperature, the sampling for analysis and laboratory testing and any other check 418 necessary to verify compliance with the food laws are performed with a frequency depending on: the risks associated with different food; the history of compliances with the requirements for the product concerned of the third Country; the controls that the food business operator importing the product has carried out and, finally, the guarantees that the competent authority of the third Country 422 of origin has given ${ }^{49}$.

In the US, the absence of adequate documentation of fish products entering the market is a serious impediment to establishing the legal origin ${ }^{50}$. Moreover, the incredible rate of adulteration of fish products found in the US market reflected not only the weak collaboration between FDA (Food and Drug Administration) and CBP (Customs and Border Protection) and NMFS (National Marine Fisheries Service), but also the inadequate attention on this issue from FDA ${ }^{51}$. Therefore, new food products coming on the market may be not properly identified.

The hypothesis that, in Italy, the commercial name adopted for Asian jellyfish is not correct seems to be confirmed by one molecular survey previously carried out in our laboratory ${ }^{12}$, which highlighted how the most part of jellyfish food products sold in Italy were $N$. nomurai instead of $R$. esculentum. Moreover, the identification of other species such as R. pulmo and P. noctiluca put in evidence the need of a revision of the commercial denomination proposed for these products. For example, the denomination of "Asian jellyfish" should be extended also to the species N. nomurai and a new denomination for the Mediterranean species $R$. pulmo should be defined. falsely labeling catches". In particular, considering the strategic position of the BIPs in the 
439 international commerce framework, it could be very important, especially in case of new products

440 (species), to establish a standardized checking procedure to be used during the inspection, to 441 correctly verify the labeling information. This could allow not only to avoid the commercialization 442 of mislabeled products, but to also clearly assess the seafood product characteristics before 443 proposing new official commercial denominations. In fact, in the case of Italy, the number of these 444 denominations has already overcome the nine hundreds ${ }^{21}$.

445 Jellyfish populations appear to be increasing in the majority of the world's coastal ecosystems 446 and seas. Due to the fact that jellyfish populations can have an important impact on human activities 447 and marine ecosystems, but, at the same time, they also represent a valuable source of food, it is 448 very important to increase the knowledge regarding the edible species actually exploited worldwide. 449 Although the DNA sequencing appears to be the most commonly applied approach for fish species 450 identification across European laboratories ${ }^{17}$, this procedure needs expensive equipment and long451 times of execution. On the countrary, the Multiplex PCR assay developed in this work represents an 452 useful test for the screening of samples and allows to speed up the analysis flow and to reduce costs. 453 Finally, this method represents a useful tool to enforce the law on traceability and to prevent 454 mislabeling in the seafood chain.

\section{$455 \quad$ Acknowledgments}

456 The Authors wish to sincerely thank Antonella Leone, Stefano Piraino and Giorgio Aglieri, who 457 kindly provided reference tissues of jellyfish.

$458 \quad$ Supporting Information description

459 Table 1SI. Reference samples obtained in this study (highlighted in grey) and in previous studies 460 (Armani et al., 2013; Pietro et al., 2013) used for the development of the Pentaplex PCR assay.

461 Table 2SI. Mismatches between the reverse specie-specific primers selected for the target jellyfish species and the sequences of other species.

\section{References}


1. Purcell, J.E.; Uye, S.I.; Lo, W.T. Anthropogenic causes of jellyfish blooms and direct consequences for humans: A review. Mar. Ecol. Prog. Ser. 2007, 350, 153-174.

2. Richardson, A.J.; Bakun A.; Hays, G.; Gibbons, M.J. The jellyfish joyride: causes, consequences and management responses to a more gelatinous future. Trends Ecol. Evol. 2009, 24(6), 312-322.

3. Boero, F. Review of jellyfish blooms in the Mediterranean and Black Sea. Studies and Reviews. General Fisheries Commission for the Mediterranean. FAO 2013, n. 92 (http://www.fao.org/docrep/017/i3169e/i3169e.pdf) (Last accessed on 22.09.2014).

4. Kang, C.; Munawir, A.; Cha, M.; Sohn, E.T.; Lee, H.; Kim, J.S.; Yoon, W.D.; Lim, D.; Kim, E. Cytotoxicity and hemolytic activity of jellyfish Nemopilema nomurai (Scyphozoa: Rhizostomeae) venom. Comp. Biochem. Phys. C. 2009, 150, 85-90.

5. Yu, H.; Liu, X.; Dong, X.; Li, C.; Xing, R.; Liu, S.; Li, P. Insecticidal activity of proteinous venom from tentacle of jellyfish Rhopilema esculenta Kishinouye. Bioorg. Med. Chem. Lett. 2005, $15,4949-4952$.

6. Ayed, Y.; Bousabbeh, M.; Mabrouk, H.B.; Morjen, M.; Marrakchi, N.; Bacha, H. Impairment of the cell-to-matrix adhesion and cytotoxicity induced by the Mediterranean jellyfish Pelagia noctiluca venom and its fractions in cultured glioblastoma cells. Lipids Health Dis. 2012, 28, 11-84.

7. Leone, A.; Lecci, R. M.; Durante, M.; Piraino, S. Extract from the Zooxanthellate Jellyfish Cotylorhiza tuberculata Modulates Gap Junction Intercellular Communication in Human Cell Cultures. Mar. Drugs, 2013, 11, 1728-1762.

8. Exposito, J.Y.; Larroux, C.; Cluzel, C.; Valcourt, U.; Lethias, C.; Degnan, B.M. Demosponge and sea anemone fibrillar collagen diversity reveals the early emergence of $\mathrm{A} / \mathrm{C}$ clades and the manteinance of the modular structure of type V/XI collagens from sponge to human. J. Biol. Chem. 2008, 283(42), 28226-28235.

9. Addad, S.; Exposito, J.Y.: Faye, C.; Ricard-Blum, S.; Lethias, C. Isolation, characterization and biological evaluation of jellyfish collagen for use in biomedical applications. Mar. Drugs 2011, 9, 967-983.

10. Hsieh, Y.H.P.; Fui-Ming Leong, F.M.; Rudloe, J. Jellyfish as food. Hydrobiologia 2001, 451,11-17.

11. Armani, A.; D’Amico, P.; Castigliego, L.; Sheng, G.; Gianfaldoni, D.; Guidi, A. Mislabeling of an "unlabelable" seafood sold on the European market: the jellyfish. Food Control 2012, 26, 247-251.

12. Armani, A.; Tinacci, L.; Giusti, A.; Castigliego, L.; Gianfaldoni, D.; Guidi, A. What is inside the jar? Forensically Informative Nucleotide Sequencing (FINS) of a short mitochondrial COI gene fragment reveals a high percentage of mislabeling in jellyfish food products. Food Res. Int. 2013, 54, 1383-1393.

13. Commission Regulation (EC) N. 2065/2001 of 22 October 2001. Laying down detailed rules for the application of Council Regulation (EC) N. 104/2000 as regards informing consumers about fishery and aquaculture products. OJ L 278, 23.10.2001, 6-8.

14. Regulation (EU) N. 1379/2013 of the European Parliament and of the Council of 11 December 2013 on the common organisation of the markets in fishery and aquaculture products, amending Council Regulations (EC) N. 1184/2006 and (EC) N. 1224/2009 and repealing Council Regulation (EC) N. 104/2000. OJ L 354, 28.12.2013, 1-21.

15. D’Amico, P.; Armani, A.; Castigliego, L.; Sheng, G.; Gianfaldoni, D.; Guidi, A. Seafood traceability issues in Chinese food business activities in the light of the European provisions. Food Control 2014, 35(1), 7-13.

16. Armani, A.; Castigliego, L.; Guidi, A. Fish fraud: The DNA challenge. CAB Reviews 2012 7, n. 71. 
17. Griffiths A. M.; Sotelo C. G.; Mendesc R.; Perez Martin R. I.; Schröderd U.; Shorten M.; Silva H. A.; Verrez-Bagnis V.; Mariani S. Current Methods for Seafood Authenticity Testing in Europe: is there a Need for Harmonisation? Food Control 2014, 45, 95-100.

18. Teletchea, F.; Maudet, C.; Hanni, C. Food and forensic molecular identification: update and challenges. Trends Biotechnol. 2005, 7, 360-366.

19. Bartlett, S. E.; Davidson, W. S. FINS (forensically informative nucleotide sequencing): A procedure for identifying the animal origin of biological specimens. Biotechniques 1992, 12(3), 408-411.

20. Cawthorn D. M.; Steinman H. A.; Witthuhn, R.C. DNA barcoding reveals a high incidence of fish species misrepresentation and substitution on the South African market. Food Res. Int. 2012, 46, 30-40.

21. Armani A.; Guardone L.; Castigliego, L.; D’Amico P.; Messina A.; Malandra R.; Gianfaldoni D.; Guidi A. DNA and Mini-DNA Barcoding for the identification of Porgies species (family Sparidae) of commercial interest on the international market. Food Control, doi: 10.1016/j.foodcont.2014.09.025.

22. Armani A.; Tinacci L.; Xiong X.; Titarenko E.; Guidi A.; Castigliego L. Development of a simple and cost-effective bead-milling method for DNA extraction from fish muscles. Food Anal. Methods 2014, 7(4), 946-955.

23. Prieto, L.; Armani, A.; Macias, D. Recent stranding of the giant jellyfish Rhizostoma luteum Quoy and Gaimard, 1827 (Cnidaria: Schyphozoa: Rhizostomeae) on the Atlantic and Mediterranean coasts. Mar. Biol. 2013, 160, 3241-3247.

24. Piraino, S.; Aglieri, G.; Martell, L.; Mazzoldi, C.; Melli, V.; Milisenda, G.; Scorrano S.; Boero, F. Pelagia benovici sp. nov.(Cnidaria, Scyphozoa): a new jellyfish in the Mediterranean Sea. Zootaxa 2014, 3794(3), 455-468.

25. Tamura K.; Peterson D.; Peterson N.; Stecher G.; Nei M.; Kumar, S. MEGA5: Molecular Evolutionary Genetics Analysis using Maximum Likelihood, Evolutionary Distance, and Maximum Parsimony Methods. Mol. Biol. Evol. 2005, 28, 2731-2739.

26. Bayha, K. M.; Dawson, M.; Collins, A. G.; Barbeitos, M. S.; Haddock, S. H. Evolutionary relationship among Scyphozoan jellyfish families based on complete taxon sampling and phylogenetic analyses of $18 \mathrm{~s}$ and 28s ribosomal DNA. Integr. Comp. Biol. 2010, 50(3), 436-455.

27. Kimura, M. A. simple method for estimating evolutionary rate of base substitutions through comparative studies of nucleotide sequences. J. Mol. Evol. 1980, 16, 111-120.

28. Armani, A.; Castigliego, L.; Tinacci, L.; Gianfaldoni, D.; Guidi, A. Multiplex conventional and real-time PCR for fish species identification of Bianchetto (juvenile form of Sardina pilchardus), Rossetto (Aphia minuta), and Icefish in fresh, marinated and cooked products. Food Chem. 2012, 133(1), 184-192.

29. Castigliego L., Armani A., Tinacci L., Gianfaldoni D., Guidi A .Two alternative multiplex PCRs for the identification of the seven species of anglerfish (Lophius spp.) using an end-point or a melting curve analysis real-time protocol. Food Chem. 2015, 166(1), 1-9

30. Russell, F.S. The medusae of the British Isles II. Pelagic Scyphozoa with a supplement to the first volume on hydromedusae. Int. Rev. Gesamten Hydrobiol. Hydrogr. 1971, 56(4), 686. Doi:10.1002/iroh.19710560438.

31. Muhammed, F.; Sultana, R. New record of edible jellyfish Rhizostoma pulmo (Cnidaria: Scyphozoa: Rhizostomatidae) from Pakistani waters. Mar. Biodivers. Rec. 2008, 1, e67 doi: http://dx.doi.org/10.1017/S1755267207007294.

32. Mariottini, G.L.; Giacco, E.; Pane, L. The Mauve Stinger Pelagia noctiluca (Forsskål, 1775). Distribution, Ecology, Toxicity and Epidemiology of Stings. A Review. Mar. Drugs. 2008, 6(3), 496-51.

33. Brotz, L.; Pauly, D. Jellyfish populations in Mediterranean Sea. Acta Adriac. 2012, 53(2), 213-232. 
34. Barbuto, M.; Galimberti, A.; Ferri, E.; Labra, M., Malandra, R.; Galli, P., Casiraghi, M. DNA barcoding reveals fraudulent substitutions in shark seafood products: The Italian case of "palombo" (Mustelus spp.). Food Res. Int. 2010, 43, 376-381.

35. Bauer, T.; Weller, P.; Hammes, W.P.; Hertel, C. The effect of processing parameters on DNA degradation in food. Eur. Food Res. Technol. 2003, 217, 338-343.

36. Kramp, PL. Synopsis of the medusae of the world. J. Mar. Biol. Ass. of UK 1961, 40, pp. 469.

37. Holst, S.; Sotje, I.; Tiemann, H.; Jarms, G. Life cycle of the rhizostome jellyfish Rhizostoma octopus (L.) (Scyphozoa, Rhizostomeae), with studies on cnidocysts and statoliths. Mar. Biol. 2007, 151, 1695-1710.

38. Dawson, M.N.; Jacobs, D.K. Molecular evidence for cryptic species of Aurelia aurita (Cnidaria, Scyphozoa). Biol, Bull. 2001, 200, 92-96.

39. Lindeman, R.; Hu, S.P.; Volpato, F.; Trent, R.J. PCR mutagenesis enabling rapid nonradioactive detection of common $\beta$-thalassemia mutations in Mediterraneans. Brit. J. Haematol. 1991, 78, 100-4.

40. Wong, W.W.K.; Chung, S.W.C.; Kwong, K. P.; Yin Ho, Y.; Xiao, Y. Dietary exposureto aluminium of the Hong Kong population. Food Addit. Contam. 2010, 27(4), 457-463.

41. Kochzius, M.; Seidel, C.; Antoniou, A.; Kumar Botla S.; Campo, D.; Cariani, A. et al. Identifying fishes through DNA barcodes and microarrays. PLOS ONE 2010, 5, e12620.

42. Markoulatos, P.; Siafakas, N.; Moncany, M. Multiplex Polymerase Chain Reaction: A Practical Approach. J. Clin. Lab. Anal. 2002, 16, 47-51.

43. Ruano, G.; Fenton, W.; Kidd, K.K.; Biphasic amplification of very dilute DNA samples via "booster" PCR. Nucleic Acids Res. 1989, 17, 5407.

44. Henegariu, O.; Heerema, N.A.; Dlouhy, S.R.; Vance, G.H.; Vogt, P.H. Multiplex PCR: critical parameters and step-by-step protocol. Biotechniques 1997, 23(3), 504-511.

45. Pelt-Verkuil E.; van Belkum, A.; Hays, J.P.; Principles and Technical Aspects of PCR Amplification, Springer Science + Business Media B.V. New York 2008; pp. 325.

46. McClatchey, K.D; Clinical laboratory medicine, 2nd edition, Lippincott Williams \& Wilkins, Philadelphia 2002; pp.1693.

47. Barnes, M.; Gibson, R.N.; Gibson, R.I; Oceanography and Marine Biology: An Annual Review, Volume 38.CRC Press, 2003; pp.439.

48. Omori, M.; Nakano, E. Jellyfish fisheries in Southeast Asia. Hydrobiologia 2001, 451(1-3), $19-26$.

49. Regulation (EC) N. 882/2004 of the European Parliament and of the Council of 29 April 2004, On official controls performed to ensure the verification of compliance with feed and food law, animal health and animal welfare rules, OJ L 191, 28.5.2004, 1-141.

50. Pramod, G.; Nakamura, K.; Pitcher, T.J.; Delagran, L; Estimates of illegal and unreported fish in seafood imports to the USA. Mar Policy 2014, 48, 102-113.

51. Timme, K.; Lowell, B.; Hirshfield, M.; Oceana study reveals seafood fraud nationwide. Oceana,2013. Available at http://oceana.org/sites/default/files/National_Seafood_Fraud_Testing_Results_Highlights_FINAL.p df.

\section{Figure caption}

Fig. 1 Electrophoresis on agarose gel (4\%) of the five species of jellyfish selected as target after the Pentaplex PCR. Line 1) C. tuberculata (72bp) ; 2) R. esculentum (101bp); 3) N. nomurai (143bp); 4) P. noctiluca (165bp); 5) R. pulmo (203bp); 6) DNA from RE product; 7) DNA from CP product; 8) H2O. DNA ladder band size: 1000 bp, 900 bp, 800 bp, 700 bp, 600 bp, 500 bp, 400 bp, 300 bp, 250 bp, 200 bp, 150 bp, 100 bp, 50 . 


\begin{tabular}{|c|c|c|c|c|c|}
\hline \multirow{3}{*}{$\begin{array}{c}\text { Samples } \\
\text { RE-2 }\end{array}$} & \multirow{3}{*}{$\begin{array}{c}\begin{array}{c}\text { City and place } \\
\text { of collection }\end{array} \\
\text { Prato / M } \\
\end{array}$} & \multirow{3}{*}{$\begin{array}{c}\begin{array}{c}\text { Sequence } \\
\text { length and } \\
\text { code }\end{array} \\
658- \\
\text { HF930536 } \\
\end{array}$} & \multicolumn{2}{|c|}{ BLAST (Max identity) } & \multirow{2}{*}{$\begin{array}{l}\text { Pentaplex PCR } \\
\text { results }\end{array}$} \\
\hline & & & Bold & GenBank & \\
\hline & & & \multicolumn{2}{|c|}{$100 \%$ N. nomurai } & $\checkmark \quad 143 \mathrm{pb}$ \\
\hline RE 3 & Prato / M & $\begin{array}{c}658- \\
\text { HF930537 }\end{array}$ & \multicolumn{2}{|c|}{$100 \%$ N. nomurai } & $\checkmark \quad 143 \mathrm{pb}$ \\
\hline RE-5 & Milan / M & $\begin{array}{c}658- \\
\text { HF930538 }\end{array}$ & \multicolumn{2}{|c|}{$100 \%$ N. nomurai } & $\checkmark \quad 143 \mathrm{pb}$ \\
\hline RE-6 & Milan / M & $\begin{array}{c}658- \\
\text { HF930539 }\end{array}$ & \multicolumn{2}{|c|}{$99 \%$ N. nomurai } & $\checkmark \quad 143 \mathrm{pb}$ \\
\hline RE-8 & Prato / M & $\begin{array}{c}658- \\
\text { HF930540 }\end{array}$ & \multicolumn{2}{|c|}{$100 \%$ N. nomurai } & $\checkmark \quad 143 \mathrm{pb}$ \\
\hline RE-9 & Prato / M & $\begin{array}{c}658- \\
\text { HF930541 }\end{array}$ & \multicolumn{2}{|c|}{$99 \% \quad N$. nomurai } & $\checkmark \quad 143 \mathrm{pb}$ \\
\hline RE-10 & Florence / M & $\begin{array}{c}658- \\
\text { HF930542 }\end{array}$ & \multicolumn{2}{|c|}{$99 \% \quad N$. nomurai } & $\checkmark \quad 143 \mathrm{pb}$ \\
\hline RE-11 & Rome / M & $\begin{array}{c}658- \\
\text { HF930543 }\end{array}$ & \multicolumn{2}{|c|}{$100 \%$ N. nomurai } & $\checkmark \quad 143 \mathrm{pb}$ \\
\hline RE-12 & Rome / M & $\begin{array}{c}658- \\
\text { HF930544 }\end{array}$ & \multicolumn{2}{|c|}{$100 \%$ N. nomurai } & $\checkmark \quad 143 \mathrm{pb}$ \\
\hline RE-13 & Rome / M & $\begin{array}{c}658- \\
\text { HF930545 }\end{array}$ & \multicolumn{2}{|c|}{$100 \%$ N. nomurai } & $\checkmark \quad 143 p$ \\
\hline RE-14 & Rome / R & $\begin{array}{c}658- \\
\text { HF930546 } \\
\end{array}$ & NM & $\begin{array}{c}100 \% \\
\text { R. esculentum }\end{array}$ & $\checkmark \quad 101 \mathrm{pb}$ \\
\hline RE-15 & Rome / M & $\begin{array}{c}6588- \\
\text { HF930547 }\end{array}$ & \multicolumn{2}{|c|}{$100 \%$ N. nomurai } & $\checkmark \quad 143 \mathrm{pb}$ \\
\hline RE-19 & Rome / M & $\begin{array}{c}658- \\
\text { HF930548 }\end{array}$ & \multicolumn{2}{|c|}{$99 \%$ N. nomurai } & $\checkmark \quad 143 p$ \\
\hline RE-21 & Florence / M & $\begin{array}{c}658- \\
\text { HF930549 }\end{array}$ & \multicolumn{2}{|c|}{$100 \%$ N. nomurai } & $\checkmark \quad 143 \mathrm{pb}$ \\
\hline RE-24 & Florence / R & $\begin{array}{c}\text { 658- } \\
\text { HF930550 }\end{array}$ & NM & $\begin{array}{c}100 \% \\
\text { R. esculentum }\end{array}$ & $\checkmark \quad 101 \mathrm{pb}$ \\
\hline RE-27 & Milan / M & $\begin{array}{c}658- \\
\text { HF930551 }\end{array}$ & \multicolumn{2}{|c|}{$99 \%$ N. nomurai } & $\checkmark \quad 143 \mathrm{pb}$ \\
\hline RE-40 & Prato / M & $\begin{array}{c}658- \\
\text { HF937280 }\end{array}$ & \multicolumn{2}{|c|}{$99 \%$ N. nomurai } & $\checkmark \quad 143 \mathrm{pb}$ \\
\hline RE-43 & Prato / R & $\begin{array}{c}658- \\
\text { HF937281 }\end{array}$ & \multicolumn{2}{|c|}{$99 \%$ N. nomurai } & NB \\
\hline RE-44 & Prato / R & $\begin{array}{c}658- \\
\text { HF937282 }\end{array}$ & NM & $\begin{array}{c}100 \% \\
\text { R. esculentum }\end{array}$ & $\checkmark \quad 101 \mathrm{pb}$ \\
\hline RE-48 & Florence/M & $\begin{array}{c}658- \\
\text { HF937283 }\end{array}$ & \multicolumn{2}{|c|}{$100 \%$ N. nomurai } & $\checkmark \quad 143 \mathrm{pb}$ \\
\hline RE-28 & Milan / M & $\begin{array}{c}206- \\
\text { HF937294 }\end{array}$ & \multicolumn{2}{|c|}{$100 \%$ N. nomurai } & $\checkmark \quad 143 \mathrm{pb}$ \\
\hline RE-29 & Milan / M & $\begin{array}{c}206- \\
\text { HF937295 }\end{array}$ & \multicolumn{2}{|c|}{$100 \%$ N. nomurai } & $\checkmark \quad 143 \mathrm{pb}$ \\
\hline RE-34 & Prato / M & $\begin{array}{c}206- \\
\text { HF937296 }\end{array}$ & \multicolumn{2}{|c|}{$100 \%$ N. nomurai } & $\checkmark \quad 143 \mathrm{pb}$ \\
\hline RE-38 & Prato / M & $\begin{array}{c}206- \\
\text { HF937297 }\end{array}$ & \multicolumn{2}{|c|}{$100 \%$ N. nomurai } & $\checkmark \quad 143 \mathrm{pb}$ \\
\hline RE-39 & Prato / M & $\begin{array}{c}206- \\
\text { HF937298 }\end{array}$ & \multicolumn{2}{|c|}{$100 \%$ N. nomurai } & $\checkmark \quad 143 \mathrm{pb}$ \\
\hline RE-41 & Prato / M & $206-$ & \multicolumn{2}{|c|}{$100 \%$ N. nomurai } & $\checkmark \quad 143 \mathrm{pb}$ \\
\hline
\end{tabular}




\begin{tabular}{|c|c|c|c|c|c|}
\hline & & HF937299 & & & \\
\hline $\mathrm{RE}-42$ & Prato / M & $\begin{array}{c}206- \\
\text { HF937300 }\end{array}$ & \multicolumn{2}{|c|}{$100 \%$ N. nomurai } & NB \\
\hline $\mathrm{RE}-45$ & Florence/M & $\begin{array}{c}206- \\
\text { HF937301 }\end{array}$ & \multicolumn{2}{|c|}{$100 \%$ N. nomurai } & NB \\
\hline RE-46 & Florence/M & $\begin{array}{c}206- \\
\text { HF937302 }\end{array}$ & \multicolumn{2}{|c|}{$100 \%$ N. nomurai } & $\checkmark \quad 143 \mathrm{pb}$ \\
\hline RE-47 & Florence/M & $\begin{array}{c}206- \\
\text { HF937303 }\end{array}$ & \multicolumn{2}{|c|}{$99 \%$ N. nomurai } & $\checkmark \quad 143 \mathrm{pb}$ \\
\hline RE-4 & Prato / M & $\begin{array}{c}206- \\
\text { HF937288 }\end{array}$ & \multicolumn{2}{|c|}{$100 \% \quad$ N. nomurai } & NB \\
\hline RE-16 & Rome / M & $\begin{array}{c}206- \\
\text { HF937289 }\end{array}$ & \multicolumn{2}{|c|}{$100 \%$ N. nomurai } & $\checkmark \quad 143 \mathrm{pb}$ \\
\hline RE-20 & Florence / M & $\begin{array}{c}206- \\
\text { HF937290 }\end{array}$ & \multicolumn{2}{|c|}{$100 \%$ N. nomurai } & $\checkmark \quad 143 \mathrm{pb}$ \\
\hline RE-23 & Florence / M & $\begin{array}{c}206- \\
\text { HF937292 }\end{array}$ & \multicolumn{2}{|c|}{$100 \%$ N. nomurai } & $\checkmark \quad 143 \mathrm{pb}$ \\
\hline RE-22 & Florence / M & $\begin{array}{c}206- \\
\text { HF937291 }\end{array}$ & \multicolumn{2}{|c|}{$100 \%$ N. nomurai } & $\checkmark \quad 143 \mathrm{pb}$ \\
\hline RE-26 & Prato / M & $\begin{array}{c}206- \\
\text { HF937293 }\end{array}$ & \multicolumn{2}{|c|}{$100 \%$ N. nomurai } & $\checkmark \quad 143 \mathrm{pb}$ \\
\hline RE-30 & Milan / M & $\begin{array}{c}145- \\
\text { HF937318 } \\
\end{array}$ & \multicolumn{2}{|c|}{$100 \%$ N. nomurai } & $\checkmark \quad 143 \mathrm{pb}$ \\
\hline RE-31 & Milan / M & $\begin{array}{c}145- \\
\text { HF937319 }\end{array}$ & \multicolumn{2}{|c|}{$100 \%$ N. nomurai } & $\checkmark \quad 143 \mathrm{pb}$ \\
\hline RE-32 & Prato / M & $\begin{array}{c}145- \\
\text { HF937320 }\end{array}$ & \multicolumn{2}{|c|}{$100 \%$ N. nomurai } & $\checkmark \quad 143 \mathrm{pb}$ \\
\hline RE-33 & Prato / M & $\begin{array}{c}145- \\
\text { HF937321 }\end{array}$ & \multicolumn{2}{|c|}{$100 \%$ N. nomurai } & $\checkmark \quad 143 \mathrm{pb}$ \\
\hline RE-35 & Prato / M & $\begin{array}{c}145- \\
\text { HF937322 }\end{array}$ & \multicolumn{2}{|c|}{$100 \%$ N. nomurai } & NB \\
\hline RE-36 & Prato / M & $\begin{array}{c}145- \\
\text { HF937323 }\end{array}$ & \multicolumn{2}{|c|}{$100 \%$ N. nomurai } & $\checkmark \quad 143 \mathrm{pb}$ \\
\hline RE-37 & Prato / M & $\begin{array}{c}145- \\
\text { HF937324 }\end{array}$ & \multicolumn{2}{|c|}{$100 \%$ N. nomurai } & $\checkmark \quad 143 \mathrm{pb}$ \\
\hline RE-1 & Prato / M & $\begin{array}{c}145- \\
\text { HF937313 }\end{array}$ & \multicolumn{2}{|c|}{$100 \%$ N. nomurai } & NB \\
\hline RE-7 & Milan / M & $\begin{array}{c}145- \\
\text { HF937314 }\end{array}$ & \multicolumn{2}{|c|}{$100 \%$ N. nomurai } & NB \\
\hline RE-17 & Rome / M & $\begin{array}{c}145- \\
\text { HF937315 }\end{array}$ & \multicolumn{2}{|c|}{$100 \%$ N. nomurai } & $\checkmark \quad 143$ \\
\hline RE-18 & Rome / M & $\begin{array}{c}145- \\
\text { HF937316 }\end{array}$ & \multicolumn{2}{|c|}{$100 \%$ N. nomurai } & $\checkmark \quad 143$ \\
\hline RE-25 & Prato / M & $\begin{array}{c}145- \\
\text { HF937317 } \\
\end{array}$ & \multicolumn{2}{|c|}{$100 \%$ N. nomurai } & $\checkmark \quad 143$ \\
\hline $\mathrm{CP}-7$ & Prato / M & $\begin{array}{c}658- \\
\text { HF937284 } \\
\end{array}$ & \multicolumn{2}{|c|}{$99 \%$ N. nomurai } & NB \\
\hline $\mathrm{CP}-8$ & Prato / M & $\begin{array}{c}658- \\
\text { HF937285 }\end{array}$ & \multicolumn{2}{|c|}{$100 \%$ N. nomurai } & 143 \\
\hline CP-24 & $\begin{array}{c}\text { Zhejiang (PRC) } \\
\text { / M }\end{array}$ & $\begin{array}{c}658- \\
\text { HF937287 } \\
\end{array}$ & $\mathrm{NM}$ & $\begin{array}{c}100 \% \\
\text { R. esculentum } \\
\end{array}$ & 101 \\
\hline CP-13 & Rome / M & $\begin{array}{c}658- \\
\text { HF937286 }\end{array}$ & $\mathrm{NM}$ & $99 \%$ R. pulmo & 203 \\
\hline CP-30 & $\begin{array}{c}\text { Jangsu (PRC) / } \\
\text { M }\end{array}$ & $658-X X$ & & N. nomurai & 143 \\
\hline CP-10 & Florence/M & $\begin{array}{c}206- \\
\text { HF937305 }\end{array}$ & 100 & N. nomurai & NB \\
\hline
\end{tabular}




\begin{tabular}{|c|c|c|c|c|c|}
\hline CP-9 & Prato / M & $\begin{array}{c}206- \\
\text { HF937304 }\end{array}$ & NM & $\begin{array}{c}100 \% \\
\text { R. esculentum }\end{array}$ & NB \\
\hline CP-11 & Rome / M & $\begin{array}{c}206- \\
\text { HF937306 }\end{array}$ & $\mathrm{NM}$ & $\begin{array}{c}100 \% \\
\text { R. esculentum }\end{array}$ & $\checkmark \quad 101$ \\
\hline CP-15 & Rome / M & $\begin{array}{c}206- \\
\text { HF937308 }\end{array}$ & \multicolumn{2}{|c|}{$100 \% \quad N$. nomurai } & $\checkmark \quad 143$ \\
\hline $\mathrm{CP}-12$ & Rome / M & $\begin{array}{c}206- \\
\text { HF937307 }\end{array}$ & \multicolumn{2}{|c|}{$100 \%$ N. nomurai } & $\checkmark \quad 143$ \\
\hline CP-18 & Florence/M & $\begin{array}{c}206- \\
\text { HF937309 }\end{array}$ & \multicolumn{2}{|c|}{$99 \%$ N. nomurai } & $\checkmark \quad 143$ \\
\hline CP-21 & Prato / M & $\begin{array}{c}206- \\
\text { HF937310 }\end{array}$ & $\mathrm{NM}$ & $\begin{array}{c}86 \% \\
\text { R. nomadica }\end{array}$ & $\checkmark \quad \mathrm{NB}$ \\
\hline $\mathrm{CP}-27$ & $\begin{array}{c}\text { Zhejiang (PRC) } \\
/ \mathrm{M}\end{array}$ & $\begin{array}{c}206- \\
\text { HF937311 }\end{array}$ & NM & $\begin{array}{c}100 \% \\
\text { P. noctiluca }\end{array}$ & $\checkmark \quad 165$ \\
\hline CP-28 & $\begin{array}{c}\text { Zhejiang (PRC) } \\
\text { / M }\end{array}$ & $\begin{array}{c}206- \\
\text { HF937312 } \\
\end{array}$ & NM & $\begin{array}{c}100 \% \\
\text { P. noctiluca }\end{array}$ & NB \\
\hline $\mathrm{CP}-1$ & Prato / M & $\begin{array}{c}145- \\
\text { HF937325 } \\
\end{array}$ & $\mathrm{NM}$ & $\begin{array}{c}100 \% \\
\text { R. esculentum }\end{array}$ & $\checkmark \quad 101$ \\
\hline $\mathrm{CP}-2$ & Prato / M & $\begin{array}{c}145- \\
\text { HF937326 }\end{array}$ & NM & $\begin{array}{l}100 \% \\
\text { R. pulmo }\end{array}$ & $\checkmark \quad 203$ \\
\hline $\mathrm{CP}-3$ & Prato / M & $\begin{array}{c}145- \\
\text { HF937327 }\end{array}$ & \multicolumn{2}{|c|}{$99 \%$ N. nomurai } & NB \\
\hline $\mathrm{CP}-4$ & Prato / M & $\begin{array}{c}145- \\
\text { HF937328 }\end{array}$ & \multicolumn{2}{|c|}{$99 \%$ N. nomurai } & $\checkmark \quad 143$ \\
\hline $\mathrm{CP}-5$ & Prato / M & $\begin{array}{c}145- \\
\text { HF937329 }\end{array}$ & NM & $\begin{array}{c}100 \% \\
\text { R. esculentum }\end{array}$ & NB \\
\hline CP-6 & Prato / M & $\begin{array}{c}145- \\
\text { HF937330 }\end{array}$ & \multicolumn{2}{|c|}{$100 \%$ N. nomurai } & $\checkmark \quad 143$ \\
\hline CP-14 & Rome / M & $\begin{array}{c}145- \\
\text { HF937331 }\end{array}$ & NM & $\begin{array}{c}100 \% \\
\text { P. noctiluca }\end{array}$ & NB \\
\hline CP-16 & Rome / M & $\begin{array}{c}145- \\
\text { HF937332 }\end{array}$ & NM & $\begin{array}{c}100 \% \\
\text { P. noctiluca }\end{array}$ & NB \\
\hline $\mathrm{CP}-17$ & Rome / M & $\begin{array}{c}145- \\
\text { HF937333 }\end{array}$ & $\mathrm{NM}$ & $\begin{array}{c}100 \% \\
\text { R. esculentum }\end{array}$ & $\checkmark \quad 101$ \\
\hline CP-19 & Prato / M & $\begin{array}{c}145- \\
\text { HF937334 }\end{array}$ & \multicolumn{2}{|c|}{$100 \%$ N. nomurai } & $\checkmark \quad 143$ \\
\hline CP-20 & Prato / M & $\begin{array}{c}145- \\
\text { HF937335 }\end{array}$ & $\mathrm{NM}$ & $\begin{array}{c}85 \% \\
\text { C. stuhlmanni }\end{array}$ & $\checkmark \quad \mathrm{NB}$ \\
\hline $\mathrm{CP}-22$ & Prato / M & $\begin{array}{c}145- \\
\text { HF937336 }\end{array}$ & $\mathrm{NM}$ & $\begin{array}{c}85 \% \\
\text { C. stuhlmanni }\end{array}$ & $\checkmark \quad \mathrm{NB}$ \\
\hline CP-23 & $\begin{array}{c}\text { Zhejiang (PRC) } \\
/ \mathrm{M}\end{array}$ & $\begin{array}{c}145- \\
\text { HF937337 }\end{array}$ & NM & $\begin{array}{c}100 \% \\
\text { P. noctiluca }\end{array}$ & NB \\
\hline CP-25 & $\begin{array}{c}\text { Zhejiang (PRC) } \\
/ \mathrm{M}\end{array}$ & $\begin{array}{c}145- \\
\text { HF937338 }\end{array}$ & $\mathrm{NM}$ & $\begin{array}{c}100 \% \\
\text { P. noctiluca }\end{array}$ & $\checkmark \quad 165$ \\
\hline CP-26 & $\begin{array}{l}\text { Zhejiang (PRC) } \\
/ \mathrm{M}\end{array}$ & $\begin{array}{c}145- \\
\text { HF937339 }\end{array}$ & $\mathrm{NM}$ & $\begin{array}{c}100 \% \\
\text { P. noctiluca }\end{array}$ & NB \\
\hline CP-29 & $\begin{array}{c}\text { Jangsu (PRC) / } \\
\text { M }\end{array}$ & $145-\mathrm{XX}$ & $\mathrm{NM}$ & $\begin{array}{c}100 \% \\
\text { R. esculentum }\end{array}$ & $\checkmark \quad 101$ \\
\hline
\end{tabular}

619 Table 1. DNA market jellyfish products identified in a previous study (Armani et al., 2013) and used in this 620 study for the validation of the Pentaplex PCR assay. RE: ready-to-eat, CP: classical products. NB: No bands. 
621

\section{2}

\begin{tabular}{|c|c|c|c|c|}
\hline Primers code & Sequence 5'-3' & bp & MT & AL \\
\hline FJ1 & CAAACCATAAAGAYATWGG & 19 & 49.1 & \\
\hline FJ2 & CAAACCATAAAGAYATTGGWAC & 22 & 53.7 & \\
\hline RHIZ1 & АССТССТАТСАAСАСТG & 17 & 50.4 & \multirow{3}{*}{203} \\
\hline RHIZ1-1 & ACGTCCTATCAACACTG & 17 & 50.4 & \\
\hline RHIZ1-2 & ACGTCGTATCAACACTG & 17 & 50.4 & \\
\hline PEL1 & TTATTAGGGCGTGAGC & 16 & 49.2 & 165 \\
\hline NEMO1 & AACTACGTTATAAAGTTGG & 19 & 50.2 & 143 \\
\hline RHOP1 & ACCTGATAGTTCTAATCTA & 19 & 48 & \multirow{2}{*}{101} \\
\hline RHOP1-1 & ACGCGATAGTTCTAATCTA & 19 & 50.2 & \\
\hline COT1 & GCCGGCACCTATAATT & 16 & 49.2 & 68 \\
\hline COT2 & GGCACCTATAATTCCG & 16 & 49.2 & 72 \\
\hline 28 sfor 55 & TGGTTACAACGGGTGA & 16 & 49.2 & \multirow{2}{*}{55} \\
\hline 28 srev55 & TCTCAGGCTCCCTCT & 15 & 50.6 & \\
\hline F28s & ACTGTGAAACTGCGAATG & 18 & 52.4 & \multirow{2}{*}{1598} \\
\hline R28s & CCATTCAATCGGTAGTAGC & 19 & 51.1 & \\
\hline
\end{tabular}

623 Table 2. Primers designed for setting up the Pentaplex PCR assay. In grey primers finally selected. $b p=$ base 624 pair; $\mathrm{MT}=$ Melting Temperature; $\mathrm{AL}=$ Amplicon length.

625 


\begin{tabular}{|c|c|c|}
\hline \multirow{2}{*}{ Species } & \multicolumn{2}{|r|}{ Sequences } \\
\hline & Number & Accession Code \\
\hline Aurelia aurita & 40 & $\begin{array}{c}\text { AY903093 - 95; AY903117- } 18 \\
\text { AY903208 - 12; HF968752 } \\
\text { JQ353726 - 28; JQ623914 } \\
\text { JX995329; KC311384-85 } \\
\text { KC440127; KC789074-93 }\end{array}$ \\
\hline Cassiopea andromeda & 24 & $\begin{array}{c}\text { AB563739-40; AY319448-62 } \\
\text { AY319471-73; AY331593-95; } \\
\text { HF930521 }\end{array}$ \\
\hline Cassiopea frondosa & 5 & $\begin{array}{l}\text { AY319467; AY319469-70 } \\
\text { HF930515; HF930520 }\end{array}$ \\
\hline Cassiopea xamachana & 5 & AY319463-66; AY319468 \\
\hline Catosylus mosaicus & 70 & $\begin{array}{c}\text { AY319476; AY737184- } 247 \\
\text { HF548537 - 39; HF968746-47 }\end{array}$ \\
\hline Cotylorhiza tuberculata & 5 & HF930531 - 35 \\
\hline Crambionella orsini & 2 & EU363343-44 \\
\hline Cyanea annaskala & 7 & AY902912-17; AY902923 \\
\hline Cyanea capillata & 21 & $\begin{array}{c}\text { AY902911; AY902924; HF930525- } \\
\text { 26; JX995329-46 }\end{array}$ \\
\hline Cyanea lamarckii & 14 & JX995347-57; JX995360-62 \\
\hline Cyanea rosea & 5 & AY902918-22 \\
\hline Drymonema dalmatinum & 5 & HQ234614-17; HQ234621 \\
\hline Drymonema larsoni & 9 & $\begin{array}{c}\text { HQ234610-13; HQ234618-20 } \\
\text { HQ234622; HQ234650 }\end{array}$ \\
\hline Lychnorhiza lucerna & 5 & HF930522; HF968748 - 51 \\
\hline Mastigias $s p$. & 132 & $\begin{array}{c}\text { AY902925-99; AY903000-51 } \\
\text { EU363340; JN215543-46 }\end{array}$ \\
\hline Nemopilema nomurai & 15 & $\begin{array}{c}\text { AB243416; EU373728; GU145135 } \\
\text { HF536563 - 70; HM045296 } \\
\text { JX845348; JQ353746 - } 47 \\
\end{array}$ \\
\hline Pelagia noctiluca & 183 & $\begin{array}{c}\text { GQ120093 - 96; GQ375903 - } 6025 \\
\text { HE591457; HF930527-30 } \\
\text { HM358383- 403; JQ697960 - } 74 \\
\text { JX235428 - } 42 \\
\end{array}$ \\
\hline Phyllorhiza punctata & 3 & EU363341-42; GQ120101 \\
\hline Rhizostoma luteum & 3 & HF937340-41; HF545309 \\
\hline Rhizostoma octopus & 63 & HQ425417-79 \\
\hline Rhizostoma pulmo & 24 & $\begin{array}{c}\text { GQ999568 - 71; HF536559 - } 62 \\
\text { HF545304 - 08; HF930513; } \\
\text { HG931669; HQ902114 - } 22 \\
\end{array}$ \\
\hline Rhopilema esculentum & 12 & $\begin{array}{c}\text { EU373722 - 24; HF536571 - } 74 \\
\text { HF930514 - 15; JQ353756 - } 57 \\
\text { JX845347 }\end{array}$ \\
\hline Rhopilema nomadica & 5 & $\begin{array}{c}\text { JN378391; HG931668; } \\
\text { HF930516-18 }\end{array}$ \\
\hline
\end{tabular}

627 Table 3. Reference sequences used in this work for the projecting of the primers for the Pentaplex PCR 628 assay. Sequences in bold have been produced in this or previous studies (Armani et al., 2013; Prieto et al, 629 2013). 


\begin{tabular}{|c|c|c|c|c|c|c|c|c|}
\hline $\begin{array}{c}\text { Sequence length } \\
\text { (with primers) }\end{array}$ & \multicolumn{2}{|c|}{709 bp } & \multicolumn{2}{c|}{ 256bp } & \multicolumn{2}{c|}{ 193bp } & \multicolumn{2}{c|}{ Total } \\
\hline & RE & CP & RE & CP & RE & CP & RE & CP \\
\hline Tested samples & 20 & 5 & 16 & 9 & 12 & 16 & 48 & 30 \\
\hline Positive samples & 19 & 4 & 13 & 5 & 9 & 8 & 41 & 17 \\
\hline $\begin{array}{c}\text { Percentage of } \\
\text { positive samples }\end{array}$ & $95 \%$ & $80 \%$ & $81 \%$ & $55.5 \%$ & $75 \%$ & $37.5 \%$ & $85.4 \%$ & $57 \%$ \\
\hline
\end{tabular}

630

631 Table 4. Amplification rate of DNA extracted from market samples using the Pentaplex PCR method. RE:

632 Ready to Eat products, CP: Classical Products. 


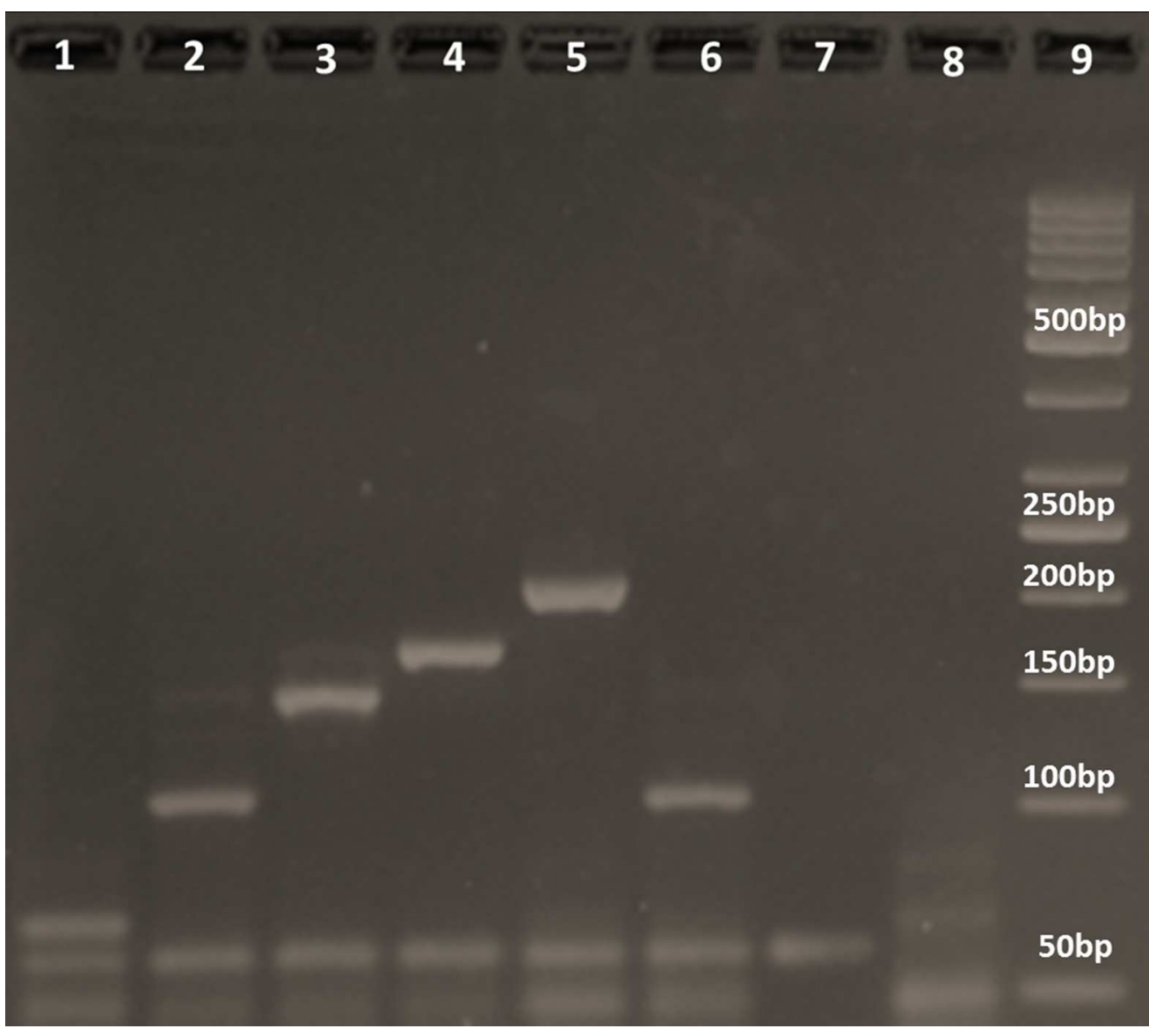

Electrophoresis on agarose gel (4\%) of the five species of jellyfish selected as target after the Pentaplex PCR. Line 1) C. tuberculata (72bp) ; 2) R. esculentum (101bp); 3) N. nomurai (143bp); 4) P. noctiluca (165bp); 5) R. pulmo (203bp); 6) DNA from RE product; 7) DNA from CP product; 8) H2O. DNA ladder band size: 1000 bp, 900 bp, 800 bp, 700 bp, 600 bp, 500 bp, 400 bp, 300 bp, 250 bp, 200 bp, 150 bp, 100 bp, 50.

$160 \times 142 \mathrm{~mm}(150 \times 150 \mathrm{DPI})$ 